\title{
FAKTOR INTERNAL PERUSAHAAN YANG MEMPENGARUHI KEBIJAKAN LINDUNG NILAI
}

\author{
Ranny Junia Setiawan \\ ranjuset@yahoo.com \\ Fakultas Ekonomi dan Bisnis, Universitas Telkom
}

diterima: 22/12/2017; direvisi: 27/2/2019; diterbitkan: 30/4/2019

\begin{abstract}
Hedging is used to protect the value of a company's assets or liabilities from exposure to fluctuations in the value of foreign currency. This study aims to investigate the conditions and influence of firm size, growth opportunities, leverage ratio, and financial distress either simultaneously or partially to the hedge policy of BUMN listed in the IDX period of 2013-2016. The sample in this study was chosen based on purposive sampling method, obtained from 16 BUMN companies with research period from 2013-2016. Data analysis technique in this research is descriptive statistical analysis and logistic regression analysis. The results of this study indicate that firm size, growth opportunities, leverage, and financial distress simultaneously have a significant effect on hedging policy. Partially, firm size and financial distress have a significant positive effect on hedging policy, leverage has a significant negative effect on hedging policy, while growth opportunity has a positive effect not significant to hedging policy.
\end{abstract}

Keywords: hedging; firm size; growth opportunities; leverage; financial distress

\begin{abstract}
Abstrak
Lindung nilai digunakan untuk melindungi nilai aset atau kewajiban perusahaan dari paparan fluktuasi nilai mata uang asing. Penelitian ini bertujuan untuk menginvestigasi kondisi dan pengaruh ukuran perusahaan, kesempatan tumbuh, rasio leverage, dan financial distress baik secara simultan maupun parsial terhadap kebijakan lindung nilai perusahaan BUMN yang terdaftar di BEI periode 2013-2016. Sampel dalam penelitian ini dipilih berdasarkan metode purposive sampling, diperoleh dari 16 perusahaan BUMN dengan periode penelitian dari 2013-2016. Teknik analisis data dalam penelitian ini adalah analisis statistik deskriptif dan analisis regresi logistik. Hasil penelitian ini menunjukan bahwa ukuran perusahaan, kesempatan tumbuh, leverage, dan financial distress secara simultan berpengaruh signifikan terhadap kebijakan lindung nilai. Secara parsial, variabel ukuran perusahaan dan financial distress berpengaruh positif signifikan terhadap kebijakan lindung nilai, variabel leverage berpengaruh negatif signifikan terhadap kebijakan lindung nilai, sedangkan variabel kesempatan tumbuh berpengaruh positif tidak signifikan terhadap kebijakan lindung nilai.
\end{abstract}

Kata Kunci: lindung nilai; ukuran perusahaan; kesempatan tumbuh; leverage; financial distress 


\section{PENDAHULUAN}

Lindung nilai (hedging) merupakan suatu tindakan yang dilakukan untuk meminimalkan risiko kerugian yang disebabkan oleh fluktuasi nilai tukar atau suku bunga di masa yang akan datang. Dalam Peraturan Menteri Keuangan no.12/PMK.08/2013 lindung nilai adalah cara yang dilakukan untuk memitigasi risiko dan melindungi aset atau kewajiban terhadap risiko fluktuasi tingkat bunga atau mata uang di masa mendatang. Aktivitas lindung nilai hampir serupa dengan membayar asuransi, karena memberikan sebuah perlindungan atau proteksi terhadap hal-hal yang tidak diinginkan dalam bisnis (Horne dan Marchowicz, 2012). Kebijakan lindung nilai dapat dilakukan dengan menggunakan instrumen derivatif, yaitu perjanjian kontrak antara pihak penjual dan pihak pembeli barang, baik komoditas maupun sekuritas, pada tanggal tertentu di masa yang akan datang dengan harga yang telah disepakati pada saat perjanjian kontrak dilakukan (Irawan, 2014).

Arus globalisasi yang semakin cepat menyebabkan banyak perusahaan mulai terlibat dalam bisnis internasional dan memberi kesempatan bagi perusahaan untuk meningkatkan kinerjanya dengan melakukan ekspor maupun impor barang, pendanaan luar negeri, serta melakukan ekspansi bisnis. Aktivitas ini mengakibatkan perusahaan berpotensi terkena dampak eksposur transaksi, operasi dan akuntansi. Dibalik keuntungan yang mungkin diterima, terdapat risikorisiko yang perlu diwaspadai perusahaan. Salah satu risikonya adalah risiko fluktuasi nilai tukar mata uang yang tidak dapat dihindari, khususnya bagi perusahaan yang memiliki arus pendapatan dan pengeluaran dalam valuta asing. Risiko ini menyebabkan ketidakpastian mengenai seberapa besar jumlah pendapatan dan jumlah beban perusahaan di masa yang akan datang. Jika perusahaan memiliki beban pada suatu mata uang asing dan mata uang asing tersebut menguat terhadap mata uang operasional perusahaan, maka perusahaan tidak dapat menghindari pertambahan beban yang diakibatkan oleh perubahan kurs tersebut (Ahmad et al., 2015).

Menteri BUMN, Rini Soemarno, menyarankan perusahaan untuk menerapkan kebijakan lindung nilai dikarenakan Indonesia Rupiah (IDR) terus berfluktuasi terhadap Dolar Amerika Serikat (USD). Fluktuasi nilai tukar ini terjadi karena Indonesia menerapkan sistem free floating rate sehingga IDR akan selalu berfluktuasi akibat faktor ekternal dan internal serta kebijakan pemerintah. (Ariani dan Sudiartha, 2017).

Gambar 1 memperlihatkan fluktuasi nilai tukar Rupiah terhadap Dollar Amerika (USD) periode 2013 hingga Triwulan II 2017. Nilai tukar adalah jumlah unit dari satu mata uang yang dapat dibeli dengan satu unit mata uang lainnya (Horne dan Marchowicz, 2012). Pada tahun 2015 hingga 2017 nilai Rupiah perlahan menguat, namun nilai tukar terhadap USD pada Triwulan II 2017 masih sangat tinggi, yaitu pada kisaran Rp 13.386,00. Nilai Rupiah yang masih lemah terhadap USD memengaruhi kegiatan perusahaan yang menggunakan valuta asing, khususnya USD, sehingga memungkinkan timbulnya dampak penting bagi laba perusahaan dan meningkatnya jumlah utang luar negeri tanpa adanya tambahan nilai manfaat dari utang tersebut. Secara langsung maupun tidak langsung, fluktuasi nilai tukar akan berdampak pada aktivitas perusahaan yang menggunakan valuta asing dalam bisnisnya dan akan menimbulkan risiko kerugian akibat meningkatnya selisih kurs. Hal ini dapat menyebabkan harga pokok produk yang tinggi, menurunnya laba perusahaan, menurunnya laba per lembar saham, dan juga memengaruhi pergerakan harga saham perusahaan.

Gambar 2 menunjukkan jumlah utang luar negeri BUMN non-bank yang ada di Indonesia periode 20132017. Berdasarkan grafik tersebut dapat disimpulkan bahwa tingkat utang luar negeri BUMN non-bank sejak tahun 2013-2017 cenderung mengalami kenaikan yang mungkin disebabkan perusahaan BUMN nonbank secara rutin mencari tambahan dana dan/atau membiayai bisnisnya menggunakan utang luar negeri. Utang luar negeri memang menjadi sumber pendanaan perusahaan baik untuk aktivitas produksi maupun untuk ekspansi bisnis, namun meningkatnya jumlah utang luar negeri juga akan meningkatkan risiko kesulitan membayar utang perusahaan akibat selisih kurs yang terus meningkat. Depresiasi yang semakin besar otomatis mengakibatkan nilai utang yang dimiliki oleh perusahaan akan membesar, ini akan menimbulkan kerugian pada perusahaan, maka untuk meminimalisirnya perusahaan dapat melakukan lindung nilai pada utang perusahaan (Dewi dan Purnawati, 2016).

Perusahaan tidak dapat menghindari risiko fluktuasi nilai tukar, namun perusahaan dapat melakukan berbagai upaya untuk meminimalkan risiko tersebut melalui manajemen risiko, yaitu sebuah usaha yang bertujuan meminimalisir kemungkinan terjadinya kerugian atas risiko. Ahmad et al. (2015), berbagai upaya yang dapat dilakukan perusahaan untuk mengindari risiko fluktuasi nilai tukar yaitu, pertama dengan membeli mata uang asing spot, yaitu membeli mata uang asing ketika kondisi ekonomi sedang stabil sehingga dapat memenuhi kebutuhan perusahaan akan mata uang asing. Kedua, menerapkan natural hedging atau lindung nilai alami, yaitu kondisi ketika beban perusahaan dengan mata uang asing dapat ditutupi oleh pendapatan perusahaan dengan mata uang asing pula, kebijakan ini dapat dilakukan tanpa adanya rekayasa keuangan. Ketiga, perusahaan dapat menerapkan perjanjian kontrak lindung nilai valuta asing sehingga dapat menekan kerugian akibat selisih kurs. Lindung nilai sebagai cara meminimalkan risiko dapat menggunakan instrumen derivatif melalui kontrak future, kontrak forward, opsi, dan swap mata uang (Horne dan Marchowicz, 2012). 
Pentingnya pendanaan usaha melalui utang luar negeri dan menimbang risiko yang mungkin timbul akibat selisih kurs yang terus meningkat, mendorong Bank Indonesia meningkatkan kesadaran perusahaan untuk menerapkan kebijakan lindung nilai serta meningkatkan pemahaman perusahaan mengenai prosedur pelaksanaannya. Menurut Deputi Gubernur Bank Indonesia, Perry Warjiyo, transaksi lindung nilai semakin penting dilakukan karena maraknya pembangunan infrastruktur di Indonesia yang pendanaannya berasal dari dalam maupun luar negeri (Rianto dan Sitorus, 2017). Bank Indonesia mengimbau perusahaan BUMN untuk melakukan transaksi lindung nilai untuk mencegah kerugian akibat lemahnya nilai tukar Rupiah terhadap USD.

Badan Pemeriksa Keuangan, Bank Indonesia, dan Kementerian Keuangan telah menyepakati pembentukan aturan mengenai lindung nilai dalam Peraturan Menteri Keuangan Nomor 12/PMK.08/2013 tentang Transaksi Lindung Nilai dalam Pengelolaan Utang Pemerintah (Miksalmina, 2015). Peraturan Menteri Keuangan tersebut mengatur mengenai pihak-pihak yang terlibat dalam transaksi lindung nilai pemerintah, proses pelaksanaan lindung nilai, penatausahaan, penganggaran dan memantau aktivitas lindung nilai. Aturan khusus mengenai lindung nilai BUMN telah diatur oleh Kementerian BUMN dalam Peraturan Menteri Badan Usaha Milik Negara Nomor Per-09/MBU/2013 tentang Kebijakan Umum Transaksi Lindung Nilai Badan Usaha Milik Negara. Dalam ketentuan ini, BUMN dapat melakukan lindung nilai dengan terlebih dahulu membuat kebijakan lindung nilai dan standard operating procedure (SOP) untuk pelaksanaannya (APBN, tanpa tahun).

Perusahaan yang menerapkan kebijakan lindung nilai dengan menggunakan instrumen derivatif diharapkan dapat memenuhi jumlah valuta asing yang dibutuhkan di masa mendatang dan terhindar dari kerugian akibat fluktuasi nilai tukar dalam jangka waktu tertentu. Meski telah melihat keuntungan dari kebijakan lindung nilai, tidak banyak perusahaan, khususnya BUMN, yang melakukan transaksi dengan mata uang asing mau menerapkan kebijakan lindung nilai dengan alasan takut merugikan perusahaan yang berdampak juga bagi kerugian negara. Permasalahan lainnya terkait lindung nilai yaitu belum adanya kesepahaman mengenai posisi lindung nilai antar pelaku ekonomi. Hal tersebut ditanggapi oleh Bank Indonesia dengan melakukan sosialisasi mengenai Standard Operating Procedure (SOP) Transaksi Lindung Nilai yang dilaksanakan pada tanggal 21 Agustus 2017 dan dihadiri oleh Staf Ahli Menteri BUMN, direktur dari tiga bank BUMN, dan 120 pejabat perusahaan BUMN, sebagai pedoman bagi BUMN untuk melakukan lindung nilai dengan instrumen derivatif (Rianto dan Sitorus, 2017).

Berbagai faktor-faktor internal dipertimbangkan perusahaan dalam mengambil keputusan untuk menerapkan kebijakan lindung nilai, salah satunya yaitu ukuran perusahaan (firm size), yaitu besar kecilnya ukuran perusahaan dilihat dari besarnya total aktiva yang dimiliki perusahaan. Kussulistyanti (2016), Guniarti (2014), Raghavendra dan Velmurugan (2014), serta Yip dan Nguyen (2012) menyatakan dengan jumlah aset yang besar, perusahaan memiliki lebih besar kemungkinan untuk menerapkan lindung nilai.

$$
\text { Ukuran Perusahaan }=\text { Ln }(\text { Total Aset })
$$

Faktor kedua yaitu kesempatan tumbuh (growth opportunity) yang digambarkan melalui proksi capital expenditure to book value of assets (CAPBVA). Rasio CAPBVA menunjukkan bahwa perusahaan akan memiliki kesempatan tumbuh yang lebih besar ketika berinvestasi untuk asetnya sendiri dan memungkinkan memperoleh laba yang lebih besar sehingga dapat membiayai investasi baru di masa mendatang. Penelitian yang telah dilakukan oleh Chiorean et al. (2012) menunjukkan bahwa CAPBVA memiliki pengaruh positif terhadap motivasi perusahaan untuk menerapkan kebijakan lindung nilai.

$$
\text { CAPBVA }=\frac{\text { Total Asset } t_{1}-\text { Total Asset } t_{0}}{\text { Total Asset } t_{1}}
$$

Tingginya tingkat utang terhadap modal juga menjadi faktor internal lain yang memengaruhi kebijakan lindung nilai perusahaan. Semakin tinggi leverage yang ditanggung perusahaan, semakin besar tindakan lindung nilai yang harus dilakukan untuk mengurangi dampak buruk risiko, sehingga semakin besar peluang perusahaan untuk mengambil keputusan lindung nilai (Damanik dan Muharam, 2015). Dewi dan Purnawati (2016) menyatakan semakin tinggi utang perusahaan, maka semakin tinggi dorongan perusahaan untuk melakukan lindung nilai, pernyataan yang sama juga disampaikan oleh Putro (2012).

$$
\text { DER }=\frac{\text { Total Utang }}{\text { Total Ekuitas }} \times 100 \%
$$

Peneliti menilai earnings per share (EPS) negatif menjadi salah satu indikator perusahaan mengalami financial distress sehingga perlu menerapkan kebijakan lindung nilai. Pemikiran tersebut didasari oleh pernyataan Platt dan Platt (2002) mengenai kebangkrutan perusahaan yang dapat ditinjau dari EPSnya. Jika perusahaan memiliki EPS positif artinya perusahaan memiliki pertumbuhan usaha yang baik, sedangkan jika EPS negatif artinya perusahaan sedang mengalami kemunduran usaha. Perusahaan yang memiliki EPS negatif akan mengalami kesulitan memperoleh dana dari eksternal sehingga akan mengalami kesulitan keuangan di masa mendatang, untuk mengatasinya perusahaan perlu menerapkan lindung nilai agar tetap 
dapat mendanai usahanya mesti sedang dalam kondisi kesulitan keuangan. Dalam penelitian ini, perusahaan yang mengalami financial distress, ditandai oleh EPS negatif diberi angka 1 dan perusahaan yang tidak mengalami financial distress, ditandai dengan EPS positif diberi angka 0 .

Penelitian ini menggunakan data dari laporan keuangan dan laporan tahunan pada perusahaan BUMN yang terdaftar di BEI periode 2013-2016. Penelitian ini terkait dengan banyaknya perusahaan BUMN yang belum menerapkan kebijakan lindung nilai, sedangkan pemerintah tengah mengimbau perusahaan BUMN untuk melakukan lindung nilai guna menekan jumlah utang luar negeri. Ketidakpastian mengenai nilai tukar Rupiah terhadap USD akan berdampak pada tingginya risiko nilai tukar valuta asing yang dinilai akan merugikan perusahaan, sehingga akan menarik untuk menganalisis faktor-faktor internal apa saja yang memengaruhi perusahaan dalam menerapkan kebijakan lindung nilai.

\section{METODE}

Penelitian ini merupakan penelitian deskriptif dan verifikatif. Populasi dalam penelitian ini adalah perusahaan BUMN yang terdaftar di BEI pada periode 2013-2016 sejumlah 20 perusahaan. Sampel dalam penelitian ini diambil menggunakan teknik purposive sampling. Perusahaan keuangan dikeluarkan dari populasi penelitian karena memiliki karakteristik highly regulated industry, dimana pengawasan dan penentuan kebijakan dilakukan oleh pemerintah melalui Bank Indonesia. Berdasarkan kriteria sampel tersebut, diperoleh 16 perusahaan dengan periode penelitian selama 4 tahun sehingga diperoleh 64 data observasi. Teknik analisis data yang digunakan dalam penelitian ini adalah analisis statistik deskriptif dan analisis regresi logistik. Penelitian ini menggunakan regresi logistik karena variabel dependen yang digunakan berupa variabel dummy, yaitu nilai 1 untuk perusahaan yang menerapkan lindung nilai dan nilai 0 untuk perusahaan yang tidak menerapkan lindung nilai.

\section{HASIL}

Berdasarkan data pada Tabel 1, dapat dilihat bahwa variabel ukuran perusahaan (size), kesempatan tumbuh (growth), dan leverage memiliki nilai mean yang lebih tinggi dari standar deviasi. Hal ini menunjukan bahwa data tidak bervariasi atau berkelompok (homogen). Sedangkan variabel financial distress memiliki nilai mean lebih rendah dari standar deviasi sehingga menunjukan bahwa data bervariasi atau tidak berkelompok (heterogen). Semakin rendah nilai standar deviasi maka semakin rendah penyimpangan data dari mean hitungnya, hal ini menyatakan bahwa sampel yang digunakan dapat mewakili seluruh populasinya.
Hasil perhitungan analisis statistik pada variabel ukuran perusahaan dari total sampel menunjukkan nilai minimum atau ukuran perusahaan sampel terkecil dimiliki oleh INAF pada tahun 2014 yaitu sebesar 27,85284, dimana INAF adalah perusahaan yang tidak menerapkan kebijakan lindung nilai. Nilai maksimum atau ukuran perusahaan sampel terbesar dimiliki oleh TLKM pada tahun 2016 sebesar 32,82181, dimana TLKM adalah perusahaan yang menerapkan kebijakan lindung nilai. Terdapat 28 sampel yang memiliki nilai di bawah mean dan 38 sampel yang memiliki nilai di atas mean.

Hasil perhitungan analisis statistik pada variabel kesempatan tumbuh dari total sampel menunjukkan nilai minimum atau kesempatan tumbuh terendah dimiliki oleh INAF pada tahun 2016 sebesar -0,11007. Nilai maksimum atau kesempatan tumbuh tertinggi dimiliki oleh WSKT tahun 2015 sebesar 0,586196. INAF maupun WSKT merupakan perusahaan yang tidak menerapkan kebijakan lindung nilai. Terdapat 41 sampel yang memiliki nilai di bawah mean dan 23 sampel yang memiliki nilai di atas mean.

Hasil perhitungan analisis statistik pada variabel leverage dari total sampel menunjukkan nilai minimum dimiliki oleh SMBR pada tahun 2014 sebesar 0,076958, dimana SMBR adalah perusahaan yang menerapkan kebijakan lindung nilai. Nilai maksimum variabel leverage dimiliki oleh ADHI pada tahun 2013 sebesar 5,27781, dimana ADHI merupakan perusahaan yang tidak menerapkan kebijakan lindung nilai.Terdapat 35 sampel yang memiliki nilai di bawah mean dan 29 sampel yang memiliki nilai di atas mean.

Hasil perhitungan analisis statistik pada variabel financial distress dari total sampel menunjukkan bahwa terdapat 9 dari 64 sampel perusahaan yang memiliki nilai EPS negatif dengan nilai mean terbesar dimiliki oleh perusahaan yang menerapkan kebijakan lindung nilai yaitu sebesar 0,22 sehingga dapat dikatanya perusahaan yang menerapkan lindung nilai cenderung memiliki nilai EPS negatif.

\section{PEMBAHASAN}

Penelitian ini bertujuan untuk menguji pengaruh ukuran perusahaan, kesempatan tumbuh, leverage, dan financial distress terhadap kebijakan lindung nilai perusahaan BUMN periode 2013-2016. Dalam penelitian ini ukuran perusahaan diproksikan melalui perhitungan logaritma natural $(\mathrm{Ln})$ dari total aset, kesempatan tumbuh diproksikan dengan capital expenditure to book value of assets (CAPBVA), leverage diproksikan dengan debt to equity ratio (DER), dan financial distress diproksikan dengan dummy EPS negatif.

Hasil pengujian kelayakan model menunjukan nilai Hosmer and Lemeshow's Goodness of Fit Test sebesar 6,698 dengan probabilitas signifikansi sebesar 0,570 dimana 0,570 >0,05 (Tabel 2). Berdasarkan 
hasil tersebut, maka hipotesis nol tidak dapat ditolak (Ho diterima). Hal ini menunjukan model regresi yang digunakan dalam penelitian ini layak dipakai untuk analisis selanjutnya karena tidak ada perbedaan yang nyata antara klasifikasi yang diprediksi dan klasifikasi yang diamati.

Hasil pengujian menunjukan nilai -2 Log likelihood (-2LL) awal sebesar 88,723 dan akhir sebesar 52,719 (Tabel 3). Dari hasil pengujian tersebut, dapat dilihat bahwa terjadi penurunan nilai -2LL di block 0 dan block 1 sebesar 36,004. Penurunan ini menunjukan bahwa secara keseluruhan model yang digunakan merupakan model yang baik, sehingga model yang dihipotesiskan fit dengan data.

Hasil pengujian menunjukan nilai Cox and Snell R Square sebesar 0,430 dan nilai Nagelkerke R Square sebesar 0,574 (Tabel 4). Berarti kombinasi antara ukuran perusahaan, kesempatan tumbuh, leverage, dan financial distress mampu menjelaskan variasi dari kebijakan lindung nilai sebesar 57,4\% dan sisanya dijelaskan oleh faktor-faktor lain yang tidak terlibat dalam penelitian ini.

Dari 32 sampel yang secara empiris tidak menerapkan kebijakan lindung nilai, sebanyak 24 sampel (75\%) secara tepat dapat diprediksikan oleh model penelitian dan 8 sampel lainnya gagal diprediksikan oleh model. Sedangkan dari 32 sampel perusahaan yang menerapkan kebijakan lindung nilai, 25 sampel $(78,1 \%)$ secara tepat dapat diprediksikan oleh model dan 7 sampel lainnya gagal diprediksikan oleh model. Secara keseluruhan tingkat ketepatan prediksi yaitu sebesar 76,6\% (Tabel 5).

Pengujian simultan dapat dilihat dari hasil pengujian Omnibus Test of Model Coefficients. Hasil pengujian menunjukan nilai Chi-square sebesar 36,004 dan degree of freedom sebesar 4, adapun tingkat signifikansi sebesar $0,000<0,05$, maka $\mathrm{H}_{0}$ ditolak atau $\mathrm{H}_{1}$ diterima (Tabel 6). Artinya variabel ukuran perusahaan, kesempatan tumbuh, leverage, dan financial distress secara bersamasama berpengaruh terhadap kebijakan lindung nilai perusahaan BUMN yang terdaftar di BEI periode 2013-2016.

Tabel 7 menampilkan hasil output yang membentuk suatu persamaan regresi logistik sebagai berikut:

$$
\begin{aligned}
\mathrm{HEDG}= & 27,228+0,964 \text { SIZE }+1,776 \text { GROWTH }- \\
& 2,126 \mathrm{LEV}+2,533 \mathrm{FD} \ldots \ldots \ldots \ldots \ldots \ldots \ldots \ldots \ldots . .(4)
\end{aligned}
$$

Ukuran perusahaan merupakan indikator yang menunjukan besarnya perusahaan dari total aset yang dimiliki. Nilai koefisien regresi pada variabel ukuran perusahaan sebesar 0,964 dengan nilai probabilitas (sig.) sebesar 0,004 dan nilai wald statistic sebesar 8,229. Nilai tersebut menyatakan bahwa ukuran perusahaan memiliki pengaruh positif yang signifikan terhadap kebijakan lindung nilai, karena memiliki nilai signifikansi yang lebih rendah dari 0,05 dan nilai wald statistic lebih besar dari nilai Chi Square Table. Berdasarkan hal tersebut, maka hipotesis satu $\left(\mathrm{H}_{1}\right)$ terdukung. Hasil penelitian ini mendukung hasil penelitian yang dilakukan oleh Kussulistyanti (2016), Guniarti (2014), Raghavendra dan Velmurugan (2014), serta Yip dan Nguyen (2012).

Kesempatan tumbuh perusahaan akan semakin besar jika perusahaan melakukan investasi pada asetnya sendiri. Nilai koefisien regresi pada variabel kesempatan tumbuh memiliki nilai sebesar 1,776 dengan tingkat probabilitas (sig.) 0,475 dan nilai wald statistic 0,510 . Hasil penelitian ini menyatakan hubungan positif tidak signifikan antara kesempatan tumbuh dan kebijakan lindung nilai karena nilai signifikansi yang lebih besar dari 0,05 dan nilai wald statistic lebih rendah dari Chi Square Table. Berdasarkan hal tersebut, maka hipotesis dua $\left(\mathrm{H}_{2}\right)$ tidak terdukung. Hasil penelitian ini mendukung penelitian yang dilakukan oleh Repie dan Sedana (2014).

Rasio leverage merupakan perbandingan antara jumlah utang dan jumlah modal yang dimiliki perusahaan. Nilai koefisien regresi variabel leverage memiliki nilai sebesar -2,126 dengan nilai probabilitas (sig.) sebesar 0,000 dan nilai wald statistic sebesar 12,528. Hasil penelitian ini menyatakan bahwa rasio leverage memiliki pengaruh negatif yang signifikan terhadap kebijakan lindung nilai karena memiliki nilai signifikansi yang lebih rendah dari 0,05 dan nilai wald statistic lebih besar dari nilai Chi Square Table. Berdasarkan hal tersebut, maka hipotesis tiga $\left(\mathrm{H}_{3}\right)$ tidak terdukung. Hasil penelitian ini mendukung hasil penelitian sebelumnya yang dilakukan oleh Widyagoca (2016) dan Ahmad (2015) yang mengatakan leverage berpengaruh negatif signifikan terhadap kebijakan lindung nilai.

Financial distress dalam penelitian ini menggunakan variabel dummy, yaitu angka 1 untuk perusahaan dengan EPS negatif dan angka 0 untuk perusahaan dengan EPS positif. Financial distress digunakan untuk mengindikasi adanya kesulitan keuangan dalam usaha. Koefisien regresi variabel financial distress bernilai sebesar 2,533 dengan probabilitas 0,042 dan nilai wald statistic sebesar 4.116. Nilai probabilitas yang lebih rendah dari 0,05 dan nilai wald statistic yang lebih rendah dari Chi Square Table menunjukan bahwa variabel financial distress memiliki pengaruh positif signifikan terhadap kebijakan lindung nilai. Berdasarkan hasil penelitian tersebut, maka hipotesis empat $\left(\mathrm{H}_{4}\right)$ terdukung. Hasil penelitian ini mendukung hasil penelitian yang dilakukan oleh Judge (2006).

\section{KESIMPULAN}

Ukuran perusahaan cenderung meningkat dari tahun ke tahun, hal ini menyatakan bahwa perusahaan sampel terus meningkatkan jumlah asetnya, sedangkan kesempatan tumbuh perusahaan sampel cenderung berfluktuasi. Rasio leverage dalam penelitian cenderung mengalami penurunan, sehingga dapat diartikan bahwa perusahaan sampel cenderung memiliki kemampuan 
untuk memenuhi kewajibannya atau mulai mengurangi penggunaan utang untuk pendanaan usahanya. Terdapat 9 dari 64 sampel yang mengalami kondisi financial distress dan kondisi ini lebih banyak dihadapi oleh perusahaan yang menerapkan lindung nilai. Dari 64 sampel, 32 sampel menerapkan lindung nilai dan 32 sampel lainnya tidak menerapkan lindung nilai.

Berdasarkan pengujian simultan, ukuran perusahaan, kesempatan tumbuh, leverage, dan financial distress secara bersama-sama berpengaruh terhadap kebijakan lindung nilai BUMN yang terdaftar di BEI periode 2013-2016. Berdasarkan pengujian parsial, ukuran perusahaan dan financial distress berpengaruh positif signifikan terhadap kebijakan lindung nilai perusahaan BUMN yang terdaftar di BEI periode 2013-2016, kesempatan tumbuh berpengaruh positif tidak signifikan terhadap kebijakan lindung nilai perusahaan BUMN yang terdaftar di BEI periode 2013-2016, sedangkan Leverage berpengaruh negatif signifikan terhadap kebijakan lindung nilai perusahaan BUMN yang terdaftar di BEI periode 2013-2016.

\section{DAFTAR PUSTAKA}

Ahmad, G. N., Mardiyati, U., \& Nashrin, A. S. 2015. Analysis of Hedging Determinants With Foreign Currency Derivative Instruments on Companies Listed on BEI Period 2012-2015. Jurnal Riset Manajemen Sains Indonesia, 544.

Ariani, N. N., \& Sudiartha, G. M. 2017. Pengaruh Leverage, Profitabilitas, dan Likuiditas terhadap Keputusan Hedging Perusahaan Sektor Pertambangan di Bursa Efek Indonesia. E-Jurnal Managemen Unud, Vol.6, No.1, 347-374.

Chiorean, R., Donohoe, M., \& Sougiannis, T. 2012. Why Do Firms Use Derivatives? Revisiting the Underinvestment Hypothesis. Working Paper, University od Illnois.

Damanik, H., \& Muharam, H. 2015. Keputusan Hedging dan Faktor-Faktor yang Mempengaruhi. Skripsi.

Dewi, K. R., \& Purnawati, K. 2016. Pengaruh Market to Book Value dan Likuiditas Terhadap Keputusan Hedging Pada Perusahaan Manufaktur di BEI. E-Jurnal Manajemen Unud.

Guniarti, F. 2014. Faktor-Faktor Yang Mempengaruhi Aktivitas Hedging Dengan Instrumen Derivatif Valuta Asing. Jurnal Dinamika Manajemen, 64-79.

Horne, J. V., \& Marchowicz, J. 2012. Fundamental of Financial Management. Buku satu edisi tiga belas. Jakarta: Salemba Empat. http://indonesia.go.id/. Retrieved from http://indonesia. go.id/?page_id=9116

Irawan, B. P. $20 \overline{14}$. Analisis Faktor yang Mempengaruhi Aktivitas Instrumen Derivatif Valuta Asing sebagai Pengambilan Keputusan Hedging. Semarang: Fakultas Ekonomi Universitas Diponegoro.

Judge, A. 2006. The Determinants of Foreign Currency Hedging by U.KNon-Financial Firms. Multinational Finance Journal, Vol.10, No.1/2, 1-41.

Klimczak, K. M. 2006. Corporate Hedging and Risk Management Theory: Evidence from Polish Listed Companies. The Journal of Risk Finance, Vol.9, No.1.

Kussulistyanti, M. J. 2016. Analisis Faktor-Faktor Yang Mempengaruhi Keputusan Hedging Dengan Derivatif Valuta Asing. Diponegoro Journal of Management, Vol. 5, No.3, 1-14.

Miksalmina. 2015. Strategi Hedging Pada Pengelolaan Hutang Luar Negeri Pemerintah Indonesia Terhadap Risiko Fluktuasi Nilai Tukar USD. QE Journal, 33.

Platt, H. D., \& Platt, M. B. 2002. Predicting Corporate Financial Distress: Reflection on Choice-Based Sample Bias. Journal of Economics and Finance 26(2), 184-199.

Putro, H. 2012. Analisis Faktor yang Mempengaruhi Penggunaan Instrumen Derivatif Sebagai Pengambilan Keputusan Hedging: Studi Kasus pada Perusahaan Automotive and Allied Products yang Terdaftar di BEI Periode 2006-2010. Diponegoro Business Review, Vol.1, No.3, 1-11.

Raghavendra, R., \& Velmurugan, P. S. 2014. The Determinants of Currency Hedging in Indian IT Firms. Journal of Business and Financial Affairs, vol.3, no.3, 1-7.

Repie, R. R., \& Sedana, I. B. 2014. Kebijakan Hedging dengan Instrumen Derivatif Dalam Kaitan dengan Underinvestment problem di Indonesia. E-Jurnal Manajemen Universitas Udayana.

Rianto, S., \& Sitorus, R. 2017. Retrieved from BUMN diimbau Hedging: http://bisnis.com

Widyagoca, I. G. 2016. Pengaruh Leverage, Growth Opportunities, dan Liquidity Terhadap Pengambilan Keputusan Heding PT Indosat Tbk. E-Jurnal Manajemen Unud, Vol.5, No.2, 1282-1308.

Yip, W. H., \& Nguyen, H. 2012. Exchange Rate Exposure and The Use of Foreign Currency Derivatives in The Australian Resources Sector. Journal of Multinational Financial Management, Vol. 22, 151-167. 
Tabel 1. Hasil Analisis Statistik Deskriptif

\begin{tabular}{lrrrrrr}
\hline \multicolumn{1}{c}{ Var } & & $\mathrm{N}$ & \multicolumn{1}{c}{ Min } & Max & Mean & Std.Dev \\
\hline SIZE & 1 & 32 & 28.5360 & 32.8218 & 30.8820 & 1.32898 \\
& 0 & 32 & 27.8528 & 31.7488 & 30.1735 & 1.0026 \\
& $\mathrm{~T}$ & 64 & 27.8528 & 32.8218 & 30.5278 & 1.22114 \\
GROWTH & 1 & 32 & -0.1252 & 0.55795 & 0.15767 & 0.11971 \\
& 0 & 32 & -0.1101 & 0.58619 & 0.17859 & 0.16012 \\
& $\mathrm{~T}$ & 64 & -0.1101 & 0.58619 & 0.16863 & 0.14068 \\
LEV & 1 & 32 & 0.07696 & 2.70094 & 0.91897 & 0.66751 \\
& 0 & 32 & 0.54632 & 5.27781 & 2.15348 & 1.40653 \\
& $\mathrm{~T}$ & 64 & 0.07696 & 5.27781 & 1.53623 & 1.25689 \\
FD & 1 & 32 & 0 & 1 & 0.22 & 0.420 \\
& 0 & 32 & 0 & 1 & 0.06 & 0.246 \\
& $\mathrm{~T}$ & 64 & 0 & 1 & 0.14 & 0.35 \\
\hline
\end{tabular}

Sumber: Hasil output SPSS 20 (2017)

Tabel 2. Hosmer and Lemeshow Test

\begin{tabular}{cccc}
\hline Step & Chi-square & df & Sig. \\
\hline 1 & 6.698 & 8 & .570 \\
\hline
\end{tabular}

Sumber : Hasil output SPSS 20 (2017)

Tabel 3. Overall Fit Model

\begin{tabular}{cc}
\hline Iteration & -2 Log likelihood \\
\hline Step 0 & 88.723 \\
Step 1 & 52.719 \\
\hline
\end{tabular}

Sumber : Hasil output SPSS 20 (2017)

Tabel 4. Model Summary

\begin{tabular}{cccc}
\hline Step & $\begin{array}{c}-2 \text { Log } \\
\text { likelihood }\end{array}$ & $\begin{array}{c}\text { Cox \& Snell R } \\
\text { Square }\end{array}$ & $\begin{array}{c}\text { Nagelkerke R } \\
\text { Square }\end{array}$ \\
\hline 1 & $52.719^{\mathrm{a}}$ & .430 & .574 \\
\hline
\end{tabular}

Sumber: Hasil output SPSS 20 (2017)

Tabel 5. Ketepatan Klasifikasi Model

\begin{tabular}{llcccc}
\hline & & \multicolumn{3}{c}{ Predicted } \\
\hline \multirow{2}{*}{ Observed } & & \multicolumn{2}{c}{ Hedging } & Percentage \\
\cline { 3 - 5 } & & No & Yes & Correct \\
\hline \multirow{2}{*}{ Step 1 } & Hedging & No & 24 & 8 & 75.0 \\
& & Yes & 7 & 25 & 78.1 \\
\hline \multicolumn{3}{c}{ Overall Percentage } & & & 76.6 \\
\hline
\end{tabular}

Sumber: Hasil output SPSS 20 (2017)
Tabel 6. Omnibus Tests of Model Coefficients

\begin{tabular}{llccc}
\hline & & Chi-square & df & Sig. \\
\hline Step 1 & Step & 36.004 & 4 & .000 \\
& Block & 36.004 & 4 & .000 \\
& Model & 36.004 & 4 & .000 \\
\hline
\end{tabular}

Sumber : Hasil output SPSS 20 (2017)

Tabel 7. Hasil Koefisien Regresi

\begin{tabular}{rlrrrr}
\hline & & \multicolumn{1}{c}{ B } & \multicolumn{1}{c}{ S.E. } & \multicolumn{1}{c}{ Wald } & \multicolumn{1}{c}{ Sig. } \\
\hline Step 1 $^{\text {a }}$ & SIZE & .964 & .336 & 8.229 & .004 \\
& GROWTH & 1.776 & 2.487 & .510 & .475 \\
& LEV & -2.126 & .601 & 12.528 & .000 \\
FD & 2.533 & 1.249 & 4.116 & .042 \\
& Constant & -27.228 & 9.925 & 7.526 & .006 \\
\hline Sumber : Data sekunder yang diolah, (2017) & &
\end{tabular}

Pergerakan Kurs IDR Terhadap USD

Tahun 2013 - TW II 2017

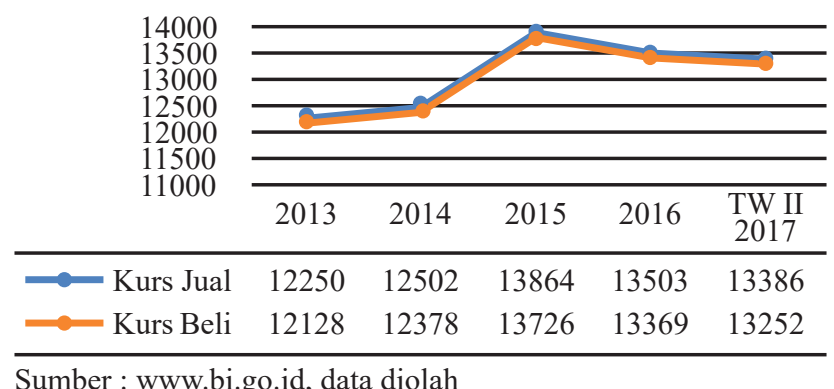

Sumber : www.bi.go.id, data diolah

Gambar 1. Pergerakan Kurs IDR Terhadap USD

Utang Luar Negeri BUMN Non-Bank Tahun 2013-2017

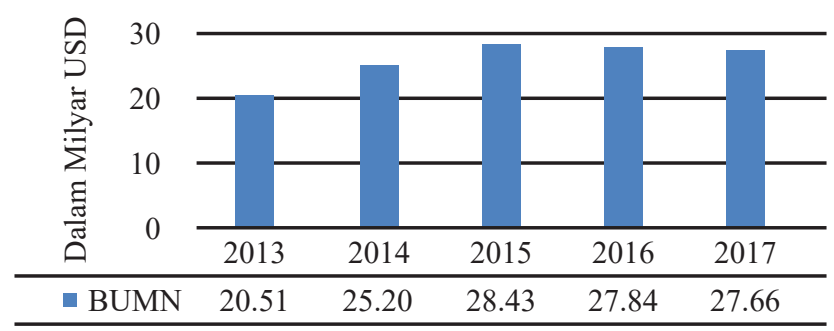

Sumber : www.bi.go.id, data diolah

Gambar 2. Jumlah Utang Luar Negeri BUMN Non-Bank 